Željko Santoši
Teaching Assistant
University of Novi Sad
Novi Sad
Serbia
Faculty of Technical Sciences
Igor Budak
Assistant Professor
University of Novi Sad
Novi Sad
Serbia
Faculty of Technical Sciences
Mario Škac
Teaching Assistant
University of Novi Sad
Faculty of Technical Sciences
Novi Sad
Serbia

\section{Bridging the Symmetry-related Gap between Physical and Digital Sculpting by Application of Reverse Engineering Modeling}

Nowadays $3 D$ technologies are integrated into all aspects of modern lives. This integration of $3 D$ technologies paved new paths for further expansion of other fields, most recently the field of arts. In this paper bridging the symmetry-related gap between physical and digital sculpting by application of reverse engineering modeling was presented. This approach enables artists to express their art in physical $3 D$ object form and then transfer it into a digital world in order to satisfy various prerequisites (here, the final $3 D$ model is to be ideally symmetrical). In order to describe this process, one case study is selected. With the use of close-range photogrammetry based on structure from motion, as a 3D digitization technique, a physical 3D model of a human head-manually sculpted in clay was digitized. In order to obtain a final physical or digital $3 D$ model of sculpted head and to make it symmetrical, the symmetry analysis and correction was performed. Namely, by comparing digitized $3 D$ model with its idealized $3 D$ model (that was created based on symmetry-correction), symmetry analysis was carried out using computer-aided inspection. The results showed critical regions of the physical i.e. its digitized $3 D$ model that, because of having no acceptable levels of dimensional deviations (regarding ideal symmetry), it must be corrected/minimized. This can be performed either by manual re-sculpting of the physical 3D model, or by modification of digitized $3 D$ model (if there is no intention to use idealized $3 D$ model for subsequent CNC-fabrication as an example).

Keywords: $3 D$ digitization, digital sculpting, reverse engineering, CAI.

\section{INTRODUCTION}

Rapid development of three-dimensional (3D) technologies has enabled their integration in different fields of application, such as biomedicine [1,2], dentistry [3], gaming industry [4], automotive industry [5], cultural heritage [6], civil and architectural engineering [7], etc. 3D technology presents a very general term and it can be defined as technology that aims to create virtual or physical 3D models using computers and other devices that support data processing in digital form [8]. Artists, now surrounded by 3D technology, can facilitate and improve their artwork by using them. Based on 3D technologies in this field digital sculpting was born.

Digital sculpting is a technique in which the artist (the creator-author) uses the computer as a tool to express (generate) his/hers creation in a 3D virtual form. The potential for the combination of 3D scanning and digital sculpting was assessed for its application to heritage industry and combining these digital tools so that the visualizer can get closer to an efficient 3D representation or reconstruction [9]. Artistic sculptures

Received: June 2018, Accepted: December 2018

Correspondence to: MSc. Željko Santoši, University of Novi Sad, Faculty of Technical Sciences, Trg Dositeja

Obradovića 6, 21000 Novi Sad, Serbia

zeljkos@uns.ac.rs

doi:10.5937/fmet1902304S

(C) Faculty of Mechanical Engineering, Belgrade. All rights reserved present a form of achievement of free-form surfaces, so these surfaces are often called sculptured or curved surfaces and may be classified as complex geometrical features [10]. Therefore in digital sculpting, because of the lack of physical interaction between the creator and the material, a loss of cohesion between the creator and the work can occur [11].

To contribute in overcoming of this problem, this paper presents one possible way of integration of reverse engineering modeling (REM) within the digital sculpting, and how to perform symmetry analysis if it's needed on a sculpted human head.

\section{REVERSE ENGINEERING MODELING}

REM is the process of data acquisition of $3 \mathrm{D}$ coordinates in a digital form from surfaces of the previously created physical object and their processing in order to obtain the virtual 3D model ready for subsequent analysis and investigation [12]. Often REM is connected with $3 \mathrm{D}$ printing, which is today the most popular 3D technology, because of the fast and easy production of complex physical models from digital models with freeform surfaces.

The basic concept of REM is shown in Figure 1. The first step is to use or create a physical 3D model and then an appropriate (or several) 3D digitization method is applied. As a result of 3D digitization, i.e. 3D 
scanning, point cloud is obtained. The pre-processing of raw 3D scanning data is often necessary due to the presence of noise in data. However, with the use of sophisticated devices for $3 \mathrm{D}$ scanning this step can be overcomed. In the final step, the "clean" point cloud is converted into a polygonal 3D mesh model or free-form 3D surface model i.e digitized 3D model.

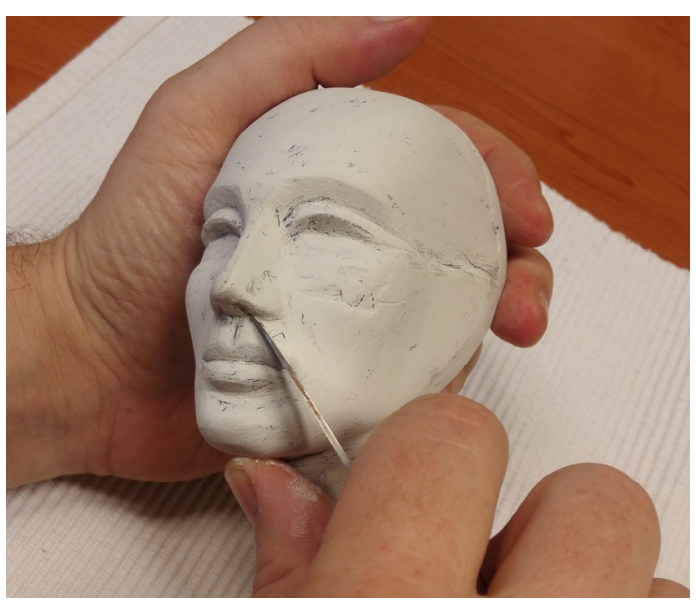

Physical sculpting

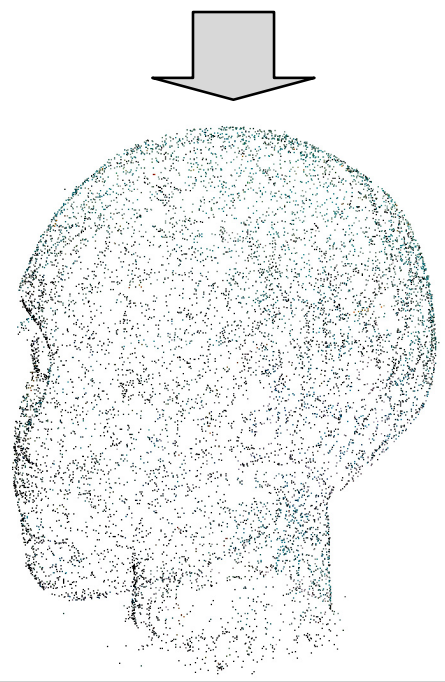

3D digitization (obtained point cloud)

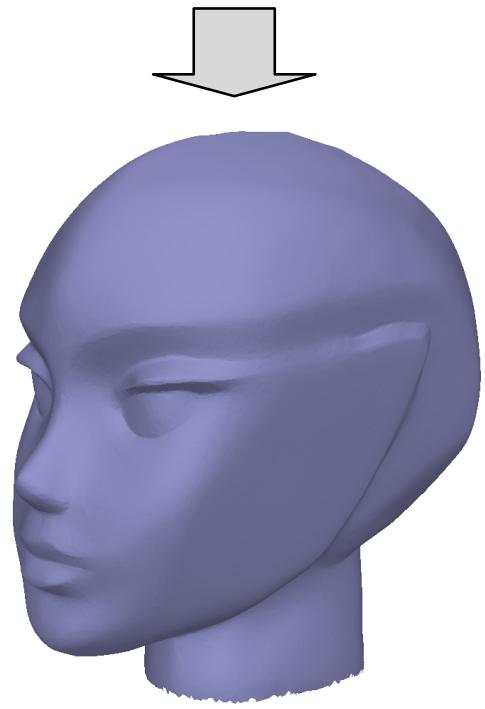

Digitized 3D model

Figure 1. Basic concept of REM
The sculptors also can use REM to produce their artworks on a much larger scale [13]. Using REM as a tool of digital sculpting enables artists to create their work in a classical manner by removing or adding material until the desired shape is reached. For this purpose, the sculptors can work with reduced dimensions, thus avoiding the need of using large amount of materials. Advantages of digital models are numerous. Geometrical changes on models can be easily implemented, as well as the applied properties of the materials, and they can be used for different types of calculations or simulations which are frequently used in engineering. This is very important, for example, when the sculpture is planned to be 10 meters tall.

Artists are becoming more interested in REM since the costs of equipment for $3 \mathrm{D}$ digitization has decreased over the last few years and became more accessible to a larger group of users.

\subsection{Physical sculpting - modeling}

The art of forming 3D shapes in materials such as stone, wood, metal, clay, marble, plastics and many other materials by using various sculpting tools for removal or addition of material is called sculpturing [11]. From sculptural techniques, modeling can be marked as a technique in which clay and wax fit perfectly, since they are materials that can be easily shaped by adding or removing them. In sculpture, the mass distribution, proportion, and symmetry are of exceptional importance, but it also varies through history from one epoch to another. In addition to the materials selected, the artist also uses modeling tools to manipulate the material into the desired shape (Figure 2.).

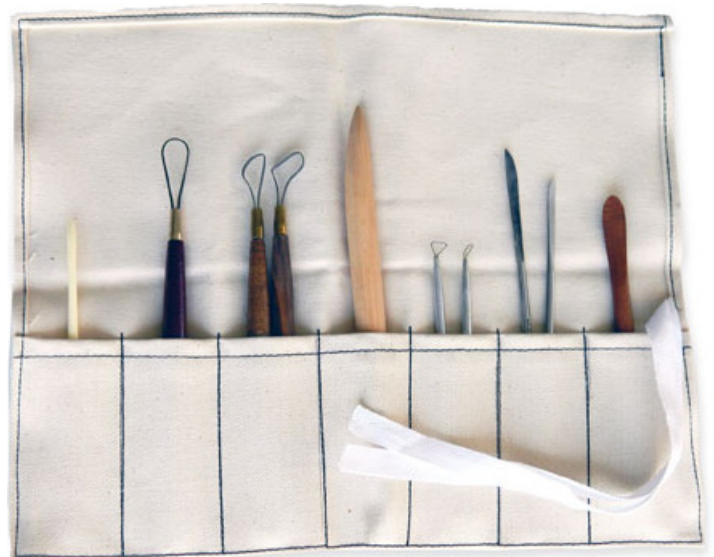

Figure 2. Modeling tools for physical sculpting [14]

These sculpting tools come in various shapes, sizes and styles and are used to cut, scrape or shape the modeling material to create a specific effect or shape. They are usually made of carbon steel, stainless steel, wood and plastic [14]. Full-sized clay models demand specially protected wood armature to protect clay from cracking and to withstand its own weight, while for small clay models, this armature is not needed.

\subsection{D digitization}

3D digitization, as an indispensable segment of REM, is amongst the most important and most complex part of 
3D model reconstruction. A large number of different $3 \mathrm{D}$ digitization methods have been developed [15], each of them with certain advantages and disadvantages. They can be classified primarily in accordance with the technology on which they are based, for example, the level of physical interaction with the object, the type of material that can be digitized, etc.

The physical 3D model used in this case study is made out of clay and the properties of this material for $3 \mathrm{D}$ digitization are very suitable for scanning by contactless or transmissive 3D digitization methods. During 3D digitization method selection, it is necessary to define the purpose, i.e. to determine which output parameter will have priority, in relation to other parameters that the output digitized 3D model should have. Also, it is important to consider other parameters from the aspect of technical realization (access to equipment) of available 3D digitization methods $[15,16]$. Amongst these parameters there should be accuracy, resolution (detail), data acquisition speed, compatibility of materials texture for $3 \mathrm{D}$ digitization, accessibility and easier equipment handling, as well as the time for subsequent processing of digitized $3 \mathrm{D}$ models. On the basis of the analysis of mentioned parameters for 3D digitization, a close-range photogrammetry based on Structure from Motion (SfM) approach was chosen [17]. This method does not require a complex hardware and software infrastructure, and it is also very flexible in terms of the dimensions of the objects that can be digitized $[18,19]$. One of the preconditions for applying this method, is that the object has pronounced visual texture [20]. This type of texture is characterized by dynamic range of colours and characteristic features that are visible on the surface of the object, regardless of its tactical texture. Since the sculptural clay, as a material, has homogeneous visual texture, it was necessary to previously correct the visual texture by making random shapes, dots and lines. The physical 3D model is then mounted on a vertical carrier, in order to provide easy access (Figure 3). The overall dimensions of the object are $80 \times 50 \times 70 \mathrm{~mm}$.

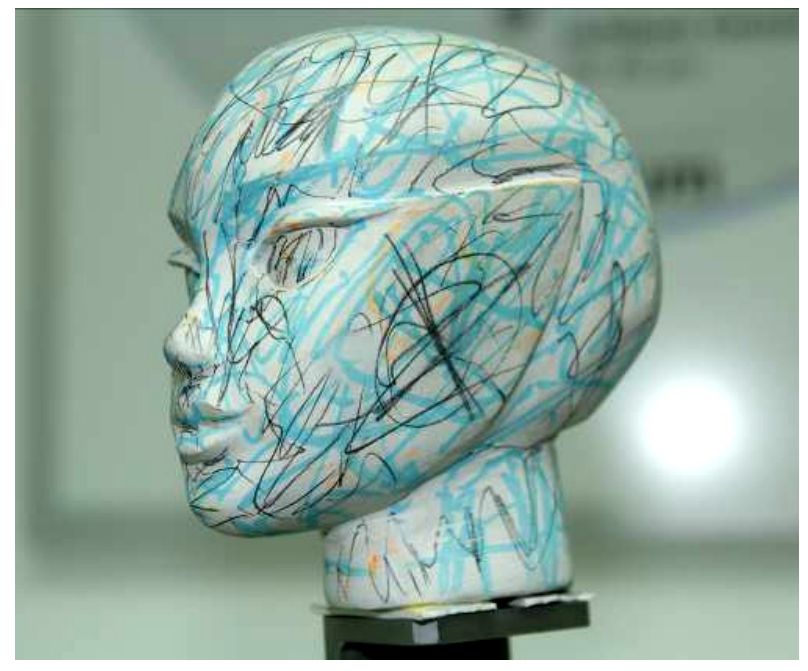

Figure 3. Prepared physical 3D model for 3D digitization

The acquisition of photographs was carried out with a DSLR camera equipped with an APS-C CMOS sensor of $22.2 \times 14.8 \mathrm{~mm}$ (crop factor 1.6) and a lens of $18-55 \mathrm{~mm}$.
The maximum resolution of this camera is $18 \mathrm{Mpix}$, and photos capturing is carried out from a distance of approximately $0.6 \mathrm{~m}$. Lens focal length of $55 \mathrm{~mm}$, aperture $\mathrm{f} / 16$ and controlled lighting conditions ensured satisfying depth of field. The smallest aperture was used to make a compromise between the field of view and the depth of field at a certain focal length. Because the physical 3D model doesn't have sharp edges, an effect of light diffraction caused by small aperture size was avoided. Due to longer shutter speeds during acquisition, camera management was performed using a laptop in order to eliminate the blurring effect of captured photos caused by vibration and/or movement of the camera during photo capturing. The achievable accuracy of the digitized 3D model is strongly dependent on various parameters that are related to both image-acquisition stage and photogrammetry input-data processing [21]. For the reconstruction of the physical 3D model, a total of 50 photographs were captured (Figure 4).
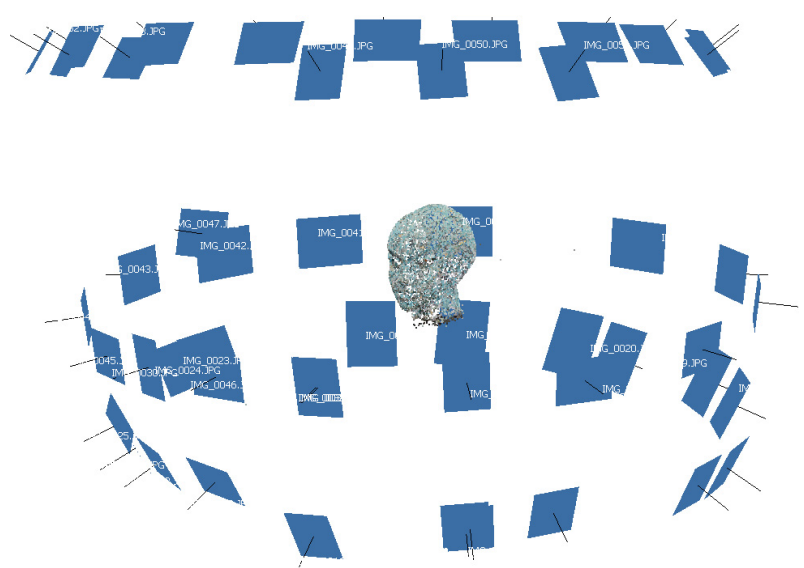

Figure 4. Camera positions during image acquisition

They were captured from three level-paths in a certain way so that the distance from the object was maintained constant, i.e. the object has not exceeded the camera depth of field. For photos processing, Agisoft PhotoScan software was used [22].

\subsection{D model generation and its idealization}

On the basis of results of 3D digitization, the digitized 3D model of the physical 3D model was generated (Figure 5. top). The ideal proportions of the human head, its form and harmony, as well as symmetry are considered as a measures of beauty [23]. Since achieving ideal symmetry by classical physical modeling is very difficult this problem can be easily solved by defining the symmetry plane. This operation was performed in Meshmixer software [24]. The next step was to remove one half of the digitized 3D model (left or right half), and then mirror the remaining half according to the defined symmetry plane. In this way an idealized 3D models of a digitized 3D model was obtained by means of achieving the ideal symmetry (Figure 5. middle). By observing idealized 3D models (Figure 5. middle) small differences in facial shape can be noticed. For further analysis, one of idealized 3D model, which is in this case obtained by mirroring right half of digitized 3D model, was used (Figure 5. bottom). 


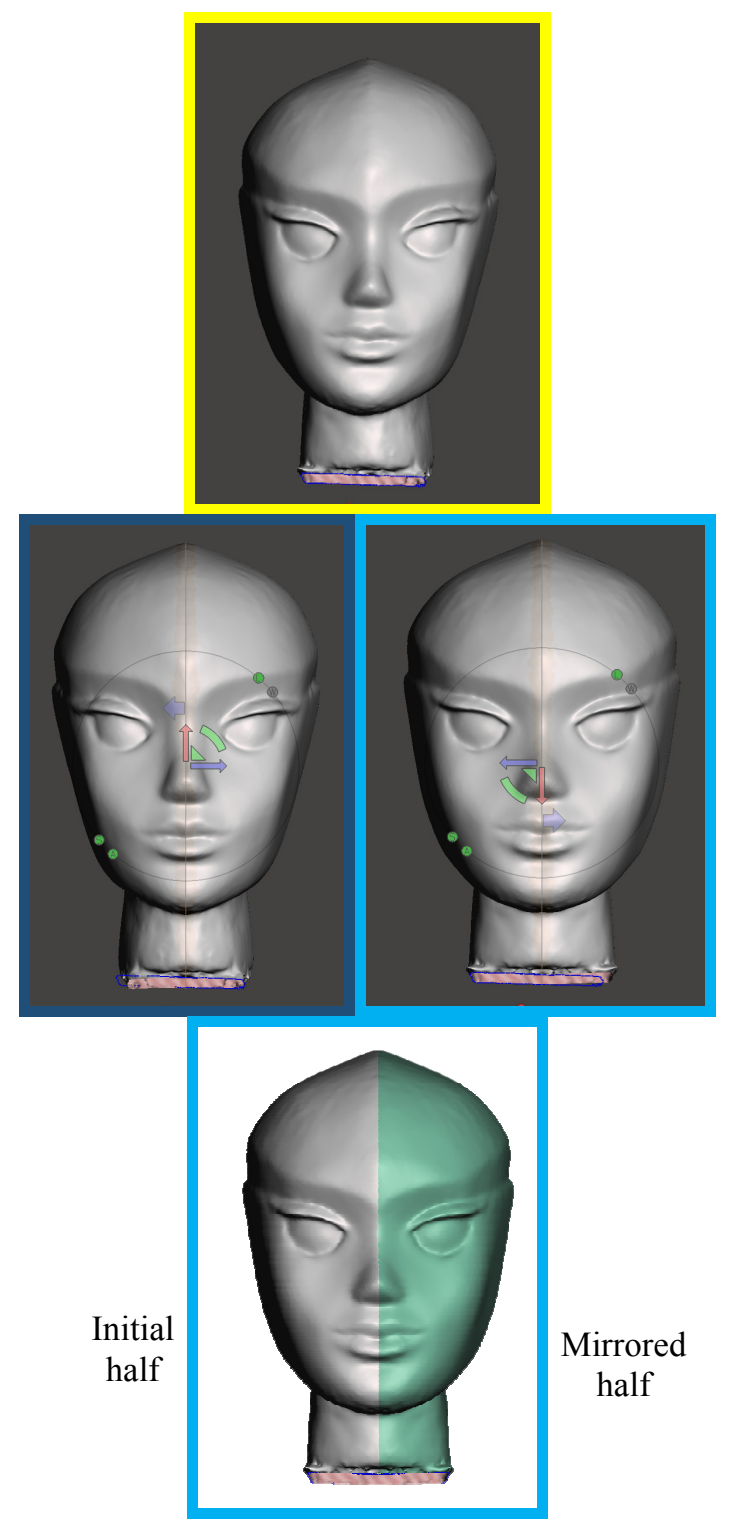

Figure 5. 3D model generated based on the 3D digitization results -digitized 3D model (top); symmetry corrected idealized 3D models (middle left/right); chosen idealized 3D model (bottom)

\section{RESULTS}

The symmetry analysis was carried out by comparing the idealized 3D model with the digitized 3D model as a reference model by Computer Aided Inspection (CAI) technique. This is performed in order to provide visual and numerical inspection, but also to identify regions that have to be readjusted/remodeled. For symmetry evaluation GOM Inspect software was used [25]. Alignment of digitized 3D model and idealized 3D model was carried out by using the "best-fit" method. One half of the idealized 3D model had flawless alignment (as expected). CAI included the inspection of complete idealized 3D model (Figure 6), specific 2D cross-section (Figure 7.) and the mirrored half of the idealized 3D model (Figure 8.). Regions marked with a light green color on the idealized 3D model represents the regions that have a very small dimensional deviation compared to the digitized 3D model (reference 3D model). Yellow, orange and red colors represent the regions that are above (positive dimensional deviations) and light blue and blue color represents the regions below (negative dimensional deviation) the reference 3D model, respectively. Inspection of the complete 3D model also includes initial half, which has flawless overlap, and the mirrored half. CAI shows that deviations are in range from $-0.729 \mathrm{~mm}$ to $+3.588 \mathrm{~mm}$. For the complete idealized 3D model calculated mean value is $+0.439 \mathrm{~mm}$ and a standard deviation distance (std) is $+0.75 \mathrm{~mm}$. Mean value presents the average value of all points included in measurement, while standard deviation is a statistical measure that represents a dissipation of measurement deviation from a mean value. The reason for low mean value is due to an ideal overlap of initial half of the 3D model.

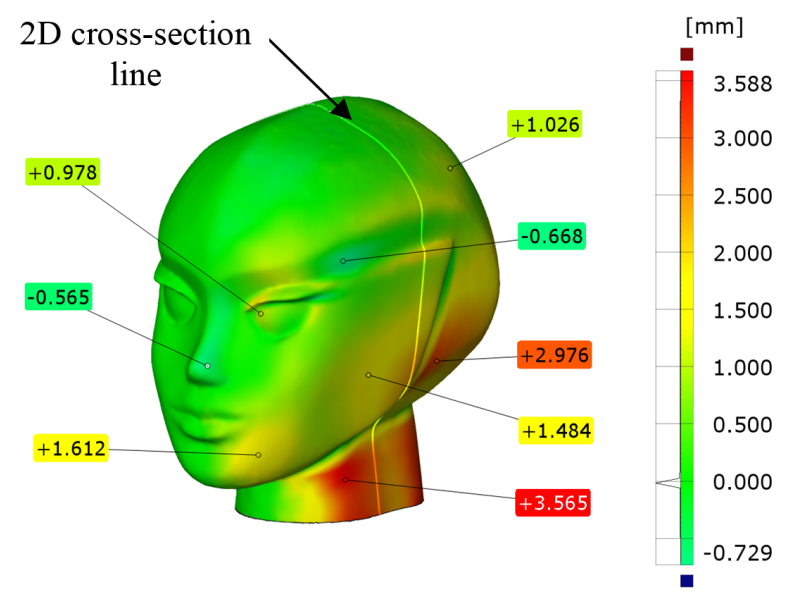

Figure 6. CAl of the complete idalized 3D model

CAI in a specific 2D cross-section (orthogonal on the symmetry plane) is very interesting from symmetry aspect. Figure 6 shows position of 2D cross-section. Figure 7 shows deviations present on defined 2D crosssection.

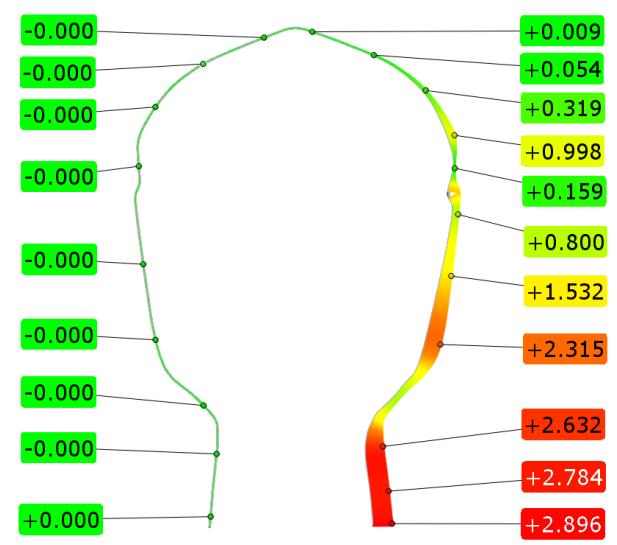

Figure 7. CAI in specific 2D cross-section

Specific 2D cross-section analysis provides a fast insight of the critical spots. As it can be seen, the left side has no deviations (as expected), while deviations on the right side varies in range from $-0.043 \mathrm{~mm}$ to $+2.922 \mathrm{~mm}$ where mean value is $+0.585 \mathrm{~mm}$ and std is $+0.886 \mathrm{~mm}$.

In order to eliminate the effect of overlapped initial (ideal) half of the 3D model, CAI was carried out only on mirrored half (shown in Figure 8). The biggest 
deviation $(+3.588 \mathrm{~mm})$ is located on the neck area and lowest $(-0.729 \mathrm{~mm})$ is located on temple area. Other positive deviations are mostly located on the occiput and neck area.

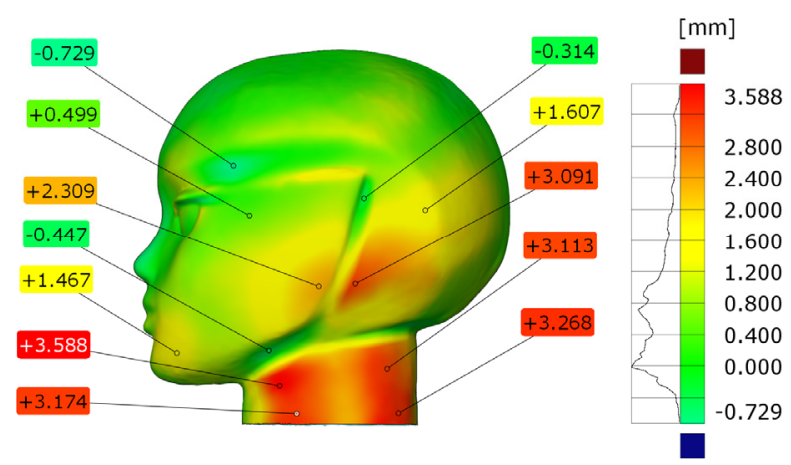

Figure 8. CAI on mirrored half of the idalized 3D model

From deviation histogram on the right side (Figure 8) much better deviation distribution can be noticed. The main deviation peak is on $0 \mathrm{~mm}$ mark, and the second deviation peak is located around $+0.8 \mathrm{~mm}$ mark. The mean value is $+0.858 \mathrm{~mm}$, while std is $+0.86 \mathrm{~mm}$. On the basis of CAI results, the idealized 3D model is bigger than the digitized 3D model, so the physical 3D model must be remodeled.

\section{CONCLUSION}

Digital sculpting, as a relatively new technique for creating free-form virtual 3D shapes, primarily represented in sculptures, can be improved and raised to a higher level with the application of REM. Artists with "trained eye" are capable of closely achieving ideal symmetry during physical sculpting, but with the use of REM that effort can be minimized. The concept of REM implementation in digital sculpting that is presented in this paper is simple and allows easy achievement of desired results. Pretty satisfactory results, as shown, can be obtained using a close range photogrammetry as a $3 \mathrm{D}$ digitization method, but other available 3D digitization methods can be applied as well. Because of its advantages in digital sculpting, it is expected that REM will continue to develop in this field, although nowadays there are various haptic devices that significantly contribute to digital sculpting which are also available. However, due to their high price, they are still inaccessible to the majority of the users.

\section{REFERENCES}

[1] Bibb, R., Eggbeer, D. and Paterson, A.: Medical Modelling The Application of Advanced Design and Rapid Prototyping Techniques in Medicine, 2nd edition. Elsevier, 2015.

[2] Sljivic, M., Stanojevic, M., Djurdjevic, D., Grujovic, N. and Pavlovic, A.: Implemenation of FEM and Rapid Prototyping in Maxillofacial Surgery, FME Transaction, Vol. 44, No. 2, pp. 422429, 2016.

[3] Trifkovic, B., Budak, I., Todorovic, A., Vukelic, D., Lazic, V. and Puskar, T.: Comparative analysis on measuring performances of dental intraoral and extraoral optical 3D digitization systems, Measurement, Vol. 47, No. 1, pp. 45-53, 2014.

[4] De la Flor, M. and Mongeon, B.: Digital Sculpting with Mudbox. Elsevier, 2010.

[5] Page, D., Koschan, A., Voisin, S., Ali, N. and Abidi, M.: 3D CAD model generation of mechanical parts using laser traingulation and laser triangulation systems, Assembly Automation, Vol. 25, No. 3, pp. 230-238, 2005.

[6] Aicardi, I., Chiabrando, F., Maria Lingua, A. and Noardo, F.: Recent trends in cultural heritage 3D survey: The photogrammetric computer vision approach, Journal of Cultural Heritage, Vol. 32, pp. 257-266, 2018.

[7] Snavely, N., Seitz, S. M. and Szeliski, R.: Modeling the World from Internet Photo Collections, International Journal of Computer Vision, Vol. 80, No. 2, pp. 189-210, 2008.

[8] Sljivic, M., Pavlovic, A., Ilic, J., Stanojevic, M. and Todorovic, S.: Comparing the accuracy of professional and consumer grade 3D printers in complex models production, FME Transaction, Vol. 45, No. 3, pp. 348-353, 2017.

[9] Frank, F., Unver, E., and Benincasa-Sharman, C.: Digital sculpting for historical representation: Neville tomb case study, Digital Creativity, Vol. 28, No. 2, pp. 123-140, 2017.

[10] Savio, E., De Chiffre, L. and Schmitt, R.: Metrology of freeform shaped parts, CIRP Annals, Vol. 56, No. 2, pp. 810-835, 2007.

[11] Burnham, J.: Beyond modern sculpture, George Braziller, Inc., New York, 1969.

[12] Page, D. et al.: Methodologies and Techniques for Reverse Engineering-The Potential for Automation with 3-D Laser Scanners, Reverse Engineering, Springer London, pp. 11-32. 2008,

[13] Newton, I. and Mills, J. P.: Photogrammetric Reverse Engineering of the 'Angel of the North', The Photogrammetric Record, Vol. 16, No. 93, pp. 457-468, 1999.

[14] Clay Modeling Tools, Materials and Supplies from Sculpture House. [Online]. Available: https://www .sculpturehouse.com/s-95-clay-modeling.aspx. [Accessed: 25-Mar-2018].

[15] Pavlidis, G., Koutsoudis, A., Fotis, A., Vassilios, T. and Christodoulos, C.: Methods for 3D digitization of Cultural Heritage, Journal of Cultural Heritage, Vol. 8, No. 1, pp. 93-98, 2007.

[16] Li, R., Luo, T. and Zha, H.: 3D digitization and its applications in cultural heritage, Lecture Notes in Computer Science (including subseries Lecture Notes in Artificial Intelligence and Lecture Notes in Bioinformatics), Vol. 6436, pp. 381-388, 2010.

[17] Wei, Y. et al.: Applications of structure from motion: a survey, Journal of Zhejiang University SCIENCE C, Vol. 14, No. 7, pp. 486-494, 2013.

[18] Koutsoudis, A. et al.: Multi-image 3D reconstruction data evaluation, Journal of Cultural Heritage, Vol. 15, No. 1, pp. 73-79, 2014. 
[19] Santosi, Z., Sokac, M., Korolija-Crkvenjakov, D., Kosec, B., Sokovic, M. and Budak, I.: Reconstruction of $3 D$ models of cast sculptures using close-range photogrammetry, Metalurgija, Vol. 54, No. 4, pp. 695-698, 2015.

[20] Nicolae, C. et al.: Photogrammetry applied to problematic artefacts, International Archives of the Photogrammetry, Remote Sensing and Spatial Information Sciences - ISPRS Archives, Vol. 40, No. 5, pp. 451-456, 2014.

[21] Luhmann, T., Robson, S., Kyle, S. and Harley, I.: Close Range Photogrammetry, Whittles Publishing, 2006.

[22] Agisoft PhotoScan, 2015. [Online]. Available: http: //www.agisoft.com/. [Accessed: 31-Aug-2018].

[23]Rhodes, G. et al.: Facial symmetry and the perception of beauty, Psychonomic Bulletin \& Review, Vol. 5, No. 4, pp. 659-669, 1998.

[24] Autodesk Meshmixer, [Online]. Available: http://www.meshmixer.com/ [Accessed: 06-Sep2018].

[25] GOM Inspect, GOM. [Online]. Available: https://www.gom.com/3d-software/gominspect.html. [Accessed: 06-Sep-2018].

\section{ПРЕМОШЋАВАЊЕ ЈАЗА У ВЕЗИ СИМЕТРИЈЕ ИЗМЕЂУ ФИЗИЧКОГ И ДИГИТАЛНОГ ВАЈАҢА ПРИМЕНОМ РЕВЕРЗИБИЛНОГ ИНЖЕЊЕРСКОГ МОДЕЛОВАЊА}

Ж. Сантоши, И. Будак, М. Шокац. Д. Павлетић
3Д технологије су данас интегрисане у све аспекте савременог живота. Ова интеграција 3Д технологија створила је нове путеве за даље ширење других области, међу којима је и област уметности. У овом раду представљено је премошћавање јаза у вези симетрије између физичког и дигиталног вајања применом реверзибилно инжењерског моделовања. Овај приступ омогућава уметницима да изразе своју кретивност у облику физичког објекта, а затим да га пренесу у дигитални свет тако да задовоље различите захтеве (овде, идеално симетричан 3Д производ). Да би то описали извршена је једна студија случаја. Наиме, употребом блиско предметне фотограметрије засноване на естимацији структуре из кретања, као методе 3Д дигитализације, физички ЗД модел људске главе ручно извајан у глини је ЗД дигитилизован. Да би се добио крајњи физички или дигитални ЗД модел извајане главе, а да би се учинио симетричним, извршена је анализа и корекција симетрије. Наиме, поређењем 3Д дигитализованог са идеално симетричним ЗД моделом (креираним на основу корекције симетрије), извршена је симетријска анализа (помоћу рачунаром подржане инспекције).

Резултати показују критичне области физичког тј. његовог дигитализованог 3Д модела, који због недостатка прихватљивих димензионих одступања (у односи на иделну симетрију) морају бити кориговани/смањени. Ово се може постићи ремоделирањем физичког 3Д модела или модификовањем дигитализованог 3Д модела (уколико нема намере користити идеализовани 3Д модел као узорак за накнадну ЦНЦ производњу). 